\title{
DISTRIBUSI ZAKAT DALAM BENTUK PENYERTAAN MODAL BERGULIR SEBAGAI ACCELERATOR KESETARAAN KESEJAHTERAAN
}

\author{
Arif Wibowo, MEI \\ Email: arif_wibowo@uny.ac.id \\ Manajemen FE, UNY, Yogyakarta
}

\begin{abstract}
The study discusses the zakat distribution on the effect of wellbeing equality by using the rolling capital investments. It is believed that zakat have a role to increase well being of citizen. However it have been yet managed well professionally. Hence, it is proposed that zakat distrubution able to improve wellbeing equality if it is managed as capital investment which applied in a proper way.
\end{abstract}

Keywords: Zakat, wellbeing, capital investment

\section{Latar Belakang Masalah}

Kemiskinan merupakan salah satu masalah yang dilami oleh hampir setiap negara. Berbagai program pengentasan kemiskinan sudah sangat banyak diupayakan, namun kemiskinan selalu saja tumbuh berbarengan dengan tumbuhnya perekonomian. Sebuah negara dengan pertumbuhan ekonomi yang tinggi ternyata tidak secara otomatis membawa kenaikan kesejahteraan (kekayaan) pada semua lapisan masyarakat. Namun, pertumbuhan ekonomi suatu negara tetap saja meninggalkan sebuah lapisan masyarakat dengan tingkat kemiskinan yang semakin parah. Kemiskinan merupakan masalah bersama, oleh karenanya, penanggulangan masalah kemiskinan juga merupakan tanggung jawab bersama.
Kepedulian sosial merupakan salah unsur pokok tegaknya kehidupan sosial. Salah satu cara menanggulangi kemiskinan adalah dengan kepedulian golongan mampu untuk memberdayakan golongan yang tidak mampu dengan mengeluarkan sebagian harta kekayaan mereka, baik berupa pembelanjaan (spending) maupun berupa dana sosial dalam wujud shadaqoh.

Shodaqoh merupakan pengeluaran (spending) untuk orang lain. Dalam ajaran syariat Islam, Shodaqah merupakan kewajiban bagi setiap orang yang mempuyai kelebihan harta dari pengeluaran wajar untuk diri dan keluarganya. Karena Shodaqah ini sifatnya wajib, maka pemberian shodaqah oleh golongan mampu ini pelaksanaannya bisa dipaksakan oleh 
pemangku kepentingan yang diberikan kewenangan. Shodaqah minimal yang pemungutannya bisa dipaksakan inilah yang kita kenal dengan istilah zakat.

Zakat merupakan salah satu instrumen openting dalam tegak dan kokohnya kehidupan suatu bangsa. Itulah mengapa dalam syariat islam, zakat merupakan satu dari lima rukun Islam. Menunaikan zakat merupakan salah satu alat bagi setiap kita untuk menunaikan peran kita sebagai manusia untuk menciptakan kebaikan (peradaban) di muka bumi ini.

Pengelolaan dana zakat di Indonesia saat ini sebagian besar masih dilakukan secara informal oleh masjid, pesantren dan melalui pemuka agama. Hal ini disebabkan oleh masih minimnya kesadaran pembayar zakat (muzakki) dan rendahnya kepercayaan terhadap Organisasi Pengelola Zakat (OPZ). Dengan kondisi seperti ini, pemaksimalan fungsi zakat dalam upaya mengentaskan kemiskinan menjadisulit diwujudkan.

\section{Definisi Zakat}

Secara bahasa (lughat), zakat berarti berkah, tumbuh dan berkembang (al-namaa), kesuburan atau bertambah (HR. At-Tirmidzi) atau dapat pula berarti membersihkan atau mensucikan (QS. AtTaubah : 10). Dinamakan zakat karena, dapat mengembangkan dan menjauhkan

harta yang telah diambil zakatnya dari bahaya. Menurut Ibnu Taimiah, hati dan harta orang yang membayar zakat tersebut menjadi suci dan bersih serta berkembang secara maknawi.

Menurut hukum Islam (istilah syara'), zakat berarti kewajiban atas harta atau kewajiban atas sejumlah harta tertentu untuk kelompok tertentu dan dalam waktu tertentu. Kewajiban atas sejumlah harta tertentu, berarti zakat adalah kewajiban atas harta yang bersifat mengikat dan bukan anjuran. Kewajiban tersebut terkena kepada setiap muslim (baligh atau belum, berakal atau gila) ketika mereka memiliki sejumlah harta yang sudah memenuhi batas nisabnya. Kelompok tertentu adalah mustakihin yang terangkum dalam delapan asnaf. Waktu untuk mengeluarkan zakat adalah ketika sudah berlalu setahun (haul) untuk zakat emas, perak, perdagangan, ketika panen untuk hasil tanaman, ketika memperolehnya untuk rikaz dan ketika bulan Ramadhan sampai sebelum shalat 'Iid untuk zakat fitrah. Hubungan antara pengertian zakat menurut bahasa dan dengan pengertian menurut istilah sangat nyata dan erat sekali, yaitu bahwa harta yang dikeluarkan zakatnya akan menjadi berkah, tumbuh, berkembang dan bertambah, suci dan baik (Hafidhuddin, 2002). 


\section{Macam-macam Zakat}

Dalam Islam, zakat terbagi menjadi dua macam sebagai berikut :

1. Zakat fitrah, yaitu zakat yang wajib ditunaikan oleh setiap muslim atas nama dirinya dan yang dibawah tanggung jawabnya, pada penghujung bulan Ramadhan, sebelum shalat Idul Fitri, bila yang bersangkutan memiliki kelebihan harta untuk keperluan pada hari itu dan malam harinya. Adapun kadar yang dibayarkan adalah satu sha' (kurang lebih 2,2 kilogram [atau yang biasa digenapkan menjadi 2,5 kilogram] dari bahan pokok setiap daerah). Menurut sebagian ulama', zakat fitrah juga bisa ditunaikan dalam bentuk nilai mata uang seharga kadar zakat tersebut, khususnya jika hal itu lebih bermanfaat bagi fakir miskin yang menerimanya. Dan karena keterkaitannya yang lebih kuat dengan diri si pembayar zakat daripada keterkaitannya dengan harta, zakat ini juga dikenal dengan sebutan zakat diri (zakatul abdaan).

2. Zakat harta (zakatul amwaal/ zakat maal), ialah zakat yang wajib ditunaikan atas kepemilikan harta dengan ketentuan-ketentuan khusus terkait dengan jenis harta, batas nominalnya (nishab), dan kadar zakatnya. Zakat ini disebut dengan zakat maal karena keterkaitannya yang lebih kuat dengan harta daripada keterkaitannya dengan diri pemiliknya. Oleh karena itu, syarat-syaratnya pun lebih banyak yang terkait dengan harta daripada dengan diri pemiliknya.

\section{Sasaran Distribusi Zakat}

Sasaran distribusi zakat disebutkan dalam Al-Qur'an surat alTawbah:60. Dalam ayat tersebut ada delapan kelompok sasaran pendistribusian zakat yaitu fakir, miskin, amil, mu'allaf, membebaskan budak (riqab), orang yang berutang (gharimin), fi sabilillah, dan ibn sabil. Berikut dijelaskan masing-masing dan penafsirannya sesuai dengan konteks sekarang.

Fakir dan Miskin. Kedua kelompok tersebut merupakan golongan masyarakat yang tidak dapat memenuhi kebutuhan pokoknya. Bedanya, kelompok fakir keadaanya lebih kurang beruntung dibanding dengan kelompok miskin (Oran dan Rashid, 1989: 128). Meskipun penentuan kriteria fakir dan miskin dengan kemampuan mereka dalam pemenuhan kebutuhan pokok ini masih relevan untuk masa sekarang, namun ukuran kebutuhan pokok itu perlu disesuaikan.

Amil Zakat. Apabila dikaitkan dengan hak penerimaan dana zakat, yang disebut amil adalah orang-orang dan atau fungsi-fungsi yang terlibat dalam salah satu dari bidang 
tanggung jawab sebagai berikut (Mas'udi, 1991):

1. Pengontrol kebijakan zakat sebagaimana disepakati oleh rakyat wajib zakat.

2. Aparat pemungut atau pencatat zakat.

3. Aparat administrasi perzakatan.

4. Segenap aparat departemen teknis yang bekerja untuk kesejahteraan rakyat dengan dana zakat.

Semua orang yang terlibat dalam salah satu dari empat tugas tersebut berhak menerima bagian dari dana zakat dalam ukuran yang disepakati.

Muallaf . Biasanya, muallaf didefinisikan sebagai orang yang tengah dibujuk untuk masuk lebih mantap ke dalam komunitas Islam. Pada masa awal Islam hal ini perlu dilakukan agar para muallaf tetap memeluk Islam dengan demikian jumlah umat Islam bisa terus berkembang dan menjadi kuat. Dengan demikian, jelas bahwa ada maksud politis strategis dalam pendistribusian dana zakat kepada kelompok ini. Khalifah Umar lah yang kemudian berinisiatif untuk tidak lagi memberikan santunan dana zakat kepada para muallaf karena pada masa itu jumlah umat Islam sudah banyak dan kuat sehingga tidak perlu lagi membujuk-bujuk para muallaf untuk tetap dalam keyakinannya.

Secara harfiah muallafati qulubuhum dalam surat al-Tawbah:60 berarti orang yang sedang dijinakkan artinya. Namun, Al-Qur'an tidak menjelaskan secara eksplisit bahwa hati mereka dijinakkan dengan dana zakat agar mereka tetap masuk dalam komunitas Islam. Dengan meminjam ijtihad Umar, pembujukan hati tersebut bukan semata bertujuan agar mereka tetap masuk dalam komunitas Muslim, tetapi lebih agar mereka memilih jalan hidup sesuai dengan jalan hidup kaum Muslim yang sebenarnya, yaitu jalan hidup yang sesuai dengan fitrah manusia.

Riqab. Untuk masa sekarang, manusia dengan status budak belian seperti ini sudah tidak ada lagi. Akan tetapi, apabila dilihat maknanya secara lebih dalam arti riqab merujuk pada kelompok manusia yang tertindak dan dieksploitasi oleh manusia lain, baik secara personal maupun struktural. Dengan kata lain, berbeda dengan istilah fakir-miskin, yang lebih merujuk pada manusia yang menderita secara sosial ekonomis, maka riqab merujuk pada orang atau masyarakat yang menderita secara budaya dan politis.

Dengan pengertian ini, dana zakat untuk kategori riqab dapat digunakan untuk "memerdekakan" orang atau kelompok masyarakat yang sedang dalam keadaan tertindas dan kehilangan haknya untuk menentukan arah hidupnya sendiri. Dengan demikian, dana zakat dapat digunakan untuk membantu buruh-buruh rendahan 
dan kuli-kuli kasar dari hegemoni majikan mereka. Sementara dalam bentuk struktural, dana zakat dapat digunakan untuk proses penyadaran dan pembebasan masyarakat tertindas berkaitan dengan hakhak dasar mereka sebagai manusia baik dalam dimensi individu maupun sosialnya (Mas'udi, 1991).

Gharimin. Untuk konteks sekarang, pengertian ini masih relevan. Akan tetapi, disamping penggunaan dana zakat yang bersifat kuratif atau memberikan bantuan setelah terjadinya kebangkrutan atau kepailitan orang yang berutang tersebut, dana zakat seharusnya juga dapat digunakan untuk mencegah terjadinya kebangkrutan tersebut dengan menyuntikkan dana agar usaha seseorang yang terancam bangkrut dapat pulih kembali dan tidak jadi pailit.

Di samping utang yang bersifat individual, utang masyarakat atau negara seharusnya juga bisa ditanggulangi dengan dana zakat. Oleh karena itu, sangat wajar kalau dana pajak yang terkumpul di negara-negara kaya digunakan dihibahkan untuk membayar hutang negara-negara miskin.

Fi Sabilillah. Istilah ini biasa diartikan sebagai tentara yang berperang di jalan Allah untuk melawan orang-orang kafir. Menurut Masdar F. Mas'udi, istilah $f i$ sabilillah memiliki dua pengertian. Dalam pengertian negatif, $f i$ sabilillah berarti berperang memerangi kekafiran. Sedangkan menurut pengertian positifnya, fi sabilillah berarti menegakkan "jalan Allah" itu sendiri (Mas'udi, 1991: 159). Jalan Allah itu diartikan sebagai "cita kebaikan-kebaikan-Nya yang universal, yang mengatasi batas kepercayaan, suku, ras, dan batas-batas formal lainnya." Rinciannya bisa macam-macam, tetapi pangkalnya adalah kemaslahatan bersama. Dalam pengertian ini, dana zakat untuk $f i$ sabilillah dapat digunakan untuk menyelenggarakan sistem kenegaraan atau pemerintahan yang mengabdi pada kepentingan rakyat, melindungi keamanan warga negara dari kekuatan-kekuatan destruktif yang melawan hak-hak kemanusiaan dan kewarganegaraan mereka yang sah, menegakkan keadilan hukum bagi warga negara, membangun dan memelihara sarana dan prasarana umum, seperti jalan, sarana komunikasi, dan sebagainya, serta usaha-usaha lain yang secara konsisten ditujuakn untuk mewujudkan cita keadilan sosial dan kesejahteraan umat manusia.

Ibn Sabil. Para fuqaha selama ini mengartikan ibnu sabil sebagai "musafir yang kehabisan bekal". Meskipun tidak salah dan masih relevan, namun pengertian ini sangat sempit. Untuk konteks sekarang, pengertian ibnu sabil dapat dikembangkan bukan sekedar pada "pelancong" yang 
kehabisan bekal, tetapi juga terhadap orang atau kelompok masyarakat yang "terpaksa" menanggung kerugian atau kemalangan ekonomi karena sesuatu yang tidak disengaja seperti karena bencana alam, wabah penyakit, dan peperangan.

Dengan pengertian ini, maka dana zakat dapat digunakan tidak saja untuk keperluan musafir yang kehabisan bekal, tetapi juga untuk keperluan pengungsi baik karena alasan politik maupun karena alasan lingkungan alam seperti banjir, tanah longsor, kebakaran, dan sebagainya.

\section{Zakat Sebagai Alat Distribusi Pendapatan}

Selama ini, pembahasan tentang sistem perekonoman selalu saja mendasarkan distribusi pendapatan dan output antar individu dalam masyarakat yang sepenuhnya dikendalikan oleh mekanisme pasar. Kekuatan permintaan dan penawaran yang akan menentukan barang-barang apa yang dihargai mahal dan barang-barang apa yang akan tidak berharga. Yang terjadi saat ini, semakin tingginya tingkat perekonomian, selalu dibarengi dengan semakin melemahnya daya beli masyarakat. Nilai kerja manusia, tidak pernah mengalami kenaikan yang signifikan, justru sebaliknya secara riil bisa dibilang menurun adalah karena lemahnya posisi penawaran tenaga kerja dan miskinnya lapangan kerja.

Distribusi atau mengalirnya pendapatan antar masyarakat hanya diwadahi dalam bentuk mekanisme kerja pasar dan tidak ada mekanisme yang secara otomatis meredistribusi pendapatan sehingga mereka yang posisi tawarnya lemah bisa meningkat. Lebih lagi, dalam perekonomian bebas berlaku hukum kesamaan harga, dimana barang/jasa akan mengalir dari suatu pasar yang harganya rendah menuju pasar yang harganya tinggi. Proses ini akan terjadi secara terus menerus sehingga harga di setiap pasar mendekati sama dan tidak menguntungkan bagi setiap pengusaha untuk mengambil keuntungan dari perbedaan harga tersebut.

Berlakunya hukum ini juga menjadi penghambat terjadinya proses distribusi pendapatan antar masyarakat. Sebagai misal naiknya tingkat upah di suatu perusahaan atau daerah tidak akan terjadi dalam jangka panjang karena hal ini akan diikuti oleh gelombang aliran tenaga kerja menuju daaerah yang upahnya tinggi hingga upah antar daerah mendekati titik yang sama.

Jika sistem ini berlangsung terus, salah satu dampaknya adalah macetnya proses distribusi yang bisa berdampak pada banyak hal termasuk aspek sosial dan politik. Ketimpangan pendapatan merupakan gejala awal dari dampak 
liberalisasi ekonomi yang bisa berujung pada kecemburuan sosial dan konflik sosial. Ekonomi liberal mengatasi masalah ini melalui kebijakan pemerintah dan mengandalkan belas kasihan para jutawan atau pilantropis.

Zakat yang merupakan kewajiban bagi setiap individu untuk mendistribusikan kelebihan kekayaan yang dimilikinya kepada orang lain yang lebih membutuhkan dharapkan bisa menjadi alternatif jawaban atas permasalahan ini. Mekanisme distribusi pendapatan dalam Islam dilekatkan kepada kewajiban orang kaya (muzakki) dengan insentif yang sangat besar, baik di dunia maupun di akhirat. Allah menjamin bahwa dengan membayar zakat (sedekah) tidak akan membuat orang miskin, bahkan hartanya di sisi Allah akan di lipat gandakan (QS 2: 276). Kepahaman masyarakat terhadap ajaran Islam akan mendorong pada mekanisme pembayaran zakat ini meskipun peran pemerintah sangatlah kecil.

\section{Zakat sebagai Insentif}

\section{Transformasi Ekonomi}

Secara empiris penyaluran zakat belum mampu memberikan dampak ekonomi yang signifikan. Hal ini terjadi, tidak lain karena pelaksanaan zakat masih bersifat parsial, baik pada aspek pemahaman, sosialisasi, maupun penerapan kebijakan perzakatan. Jika zakat mampu dipahami secara utuh dan dilaksanakan secara berjamaah dalam suatu negara, maka tidak disanksikan bahwa zakat akan memiliki manfaat ekonomi yang luar biasa besar.

Sistem ekonomi berbasis zakat mampu mendorong proses transformasi ekonomi dan sekaligus mempercepat proses distribusi pendapatan dan kesejahteraan sosial dalam masyarakat. Sistem zakat sebagai suatu sistem ekonomi ini telah dipraktekkan dan dibuktikan oleh Nabi Muhammad SAW dan pemerintahan Khulafa'al-Rasidin.

\section{Zakat Sebagai Alat Redistribusi Pendapatan dan Kekayaan}

Distribusi pendapatan dalam Islam merupakan penyaluran harta yang ada, baik yang dimiliki oleh pribadi atau umum (publik) kepada pihak yang berhak menerima dengan tujuan untuk meningkatkan kesejahteraan masyarakat, sesuai dengan peraturan yang ada dalam islam (syaria't). Kewajiban menyisihkan sebagian harta bagi pihak yang berkecukupan (muzakki atau surplus units) diyakini sebagai kompensasi atas kekayaannya dan di sisi lain merupakan insentif (perangsang) untuk kekayaan pihak yang kekurangan (mustahik atau deficit units) agar dapat dikembangkan kepada yang lebih baik (surplus). 
Konsep optimalisasi proses redistribusi pendapatan dan kekayaan yang ditawarkan Islam tercermin pada kewajiban zakat yang dibebankan kepada masyarakat yang kaya (muzakki) dan didistribusikan kepada masyarakat miskin (mustahik). Ada dua peran zakat dalam meningkatkan keadilan distribusi pendapatan :

1. Zakat berfungsi untuk mengurangi tingkat pendapatan yang siap dikonsumsi (disposable income) oleh kelompok masyarakat kaya (muzakki). Oleh karena itu, pengimplementasian zakat diharapkan akan mampu mengerem tingkat konsumsi orang kaya. Hal ini pada gilirannya akan memiliki dampak yang positif, yaitu menurunnya dampak meningkatkan harga-harga komoditas.

2. Zakat berfungsi sebagai media transfer pendapatan sehingga mampu meningkatkan daya beli masyarakat miskin. Dalam hal ini diharapkan dengan menerima zakat, maka segmen masyarakat miskin akan meningkat daya belinya sehingga mampu berinteraksi dengan segmen masyarakat kaya.

Al-Qur'an telah menjelaskan penentuan alokasi zakat, siapa yang berhak menerimanya, tetapi tidak dijelaskan apakah yang zakat itu harus diterima dalam bentuk uang, barang-barang konsumsi atau modal kerja. Hal ini menimbulkan pemikiran yang melahirkan ide ide bagaimana agar zakat memberikan dampak yang lebih baik bagi para penerima. Sehingga zakat yang diberikan dapat lebih mengarah pada zakat produktif.

Beberapa ide yang sudah muncul diantaranya, pengelolaan zakat yang dilakukan dengan konsep snow ball dalam penggunaan harta zakat yang sudah terkumpul. Maksudnya adalah, ketika tahun ini seorang individu menjadi penerima zakat produktif, maka pada tahun depan, diharuskan penerima tadi dapat menjadi pembayar zakat.Zakat, apabila dikelola dengan baik maka akan menjadi salah satu solusi untuk menciptakan kesejahteraan bagi masyarakat.

Distribusi Zakat Dalam Bentuk Penyertaan Modal Bergulir dengan Sistem Bagi Hasil .

Pelaksanaan pengamalan zakat, harus ditangani oleh lembaga amil zakat yang memiliki sistem manajemen fungsional dan profesional. Hal tersebut diharapkan akanmemberikan hasil yang optimal dan efektif atas efek zakat dalam transformasi ekonomi. Seperti yang pernah diusukan oleh Dawam Rahardjo akan perlunya bank sosial Islam, Bank ini berfungsi mengelola dana zakat untuk didayagunakan bagi kepentingan pemberdayaan ekonomi ummat.

Menurut Kuntowijoyo, zakat yang merupakan salah satu instrumen penting 
dalam Islam sebagai upaya untuk menciptakan kesejahteran sosial perlu dibentuk institusi bank yang bebas bunga (zero interest bank) sebagai pengelola dana ummat berupa zakat dan sumber lainnya, yang ditujukan untuk membantu permodalan bagi masyarakat ekonomi lemah.

Dana zakat dapat digunakan untuk usaha-usaha kecil, seperti industri rumah tangga (home industry), pertukangan, perbengkelan dan jasa. Dengan demikian diharapkan dapat terciptanya pemerataan kesejahteraan sosial ekonomi masyarakat, dengan meningkatnya daya beli masyarakat, dan beredarnya harta kekayaan secara berkeadilan.

Untuk alasan inilah maka menjadi penting melakukan upaya-upaya untuk meningkatkan efektifitas pendayagunaan zakat. Dengan keterbatasan dana zakat, diperlukan strategi pendistribusian yang tepat agar zakat menjadi efektif.

Ada tiga hal penting yang harus mendapatkan penekanan dalam upaya meningkatkan efektifitas dan kemanfaat gunaan pendistribusian zakat, yaitu:

Pertama, prioritas target distribusi zakat. Distribusi zakat sudah ditentukan hanya untuk delapanashnaf (QS 9: 60). Namun demikian, Al Qur'an menyebutkan fakir dan miskin sebagai kelompok pertama dan kedua dalam daftar penerima zakat. Mereka inilah yang mendapat prioritas dan pengutamaan oleh Al Qur'an. Ini menunjukkan bahwa mengatasi masalah kemiskinan merupakan tujuan utama zakat. Hal ini menjadi sangat penting ketika dana zakat adalah terbatas. Untuk mewujudkan kemaslahatan, diperbolehkan tidak menyamaratakan pemberian zakat pada semua sasaran zakat, bahkan diperbolehkan memberikan zakat untuk satu sasaran saja.

Kedua, bentuk pendistribusian zakat yang sesuai. Kadar zakat untuk fakir miskin tidak ditentukan menurut besarnya dana zakat yang terkumpul. Hal ini karena tujuan zakat adalah memberikan tingkat hidup yang layak sebagai seorang Muslim dengan cara memampukan mustahik untuk menghidupi diri-nya sendiri dengan kemampuan yang dimilikinya. Bagi fakir miskin yang sanggup bekerja namun menjadi miskin karena tidak dapat menggunakan secara penuh sumber daya mereka karena keterbatasan modal manusia (human capital), modal fisik (physical capital), dan modal finansial (financial capital) yang dibutuhkan untuk melakukan aktivitas ekonomi agar memperoleh pendapatan yang layak, zakat harus ditujukan sebagai modal produktif. Disini zakat harus dijadikan sebagai program spesifik yang di desain untuk mendukung penyediaan modal manusia, fisik, dan finansial yang dibutuhkan orang miskin. 
Pemberian modal produktif mungkin tidak sesuai untuk kelompok pekerja atau buruh miskin yang memiliki keterbatasan waktu dan kontrak kerja. Disini zakat dapat ditujukan sebagai equity transfer yaitu pemberian zakat dalam bentuk modal saham sehingga pekerjaburuh miskin mendapat manfaat dari aktivitas ekonomi yang luas, meningkatnya motivasi kerja, dan nilai saham yang cenderung stabil. Sedangkan bagi fakir miskin yang tidak sanggup bekerja dan mencari nafkah, zakat dapat ditujukan sebagai jaring pengaman sosial. Disini zakat dapat digunakan untuk menyediakan kebutuhan dasar kelompok orang tua dan jompo, orang-orang sakit dan cacat, dan anak-anak terlantar.

Ketiga, menyesuaikan dengan kondisi lokal dan perkembangan terkini. Lembaga zakat perlu untuk memikirkan bentuk pendayagunaan zakat yang sesuai dengan kondisi dan kebutuhan masyarakat lokal serta perkembangan pemikiran tentang pemberdayaan ekonomi masyarakat. Sebagai misal, dalam kondisi bencana alam, distribusi zakat semestinya tidak hanya dalam bentuk cash transfer namun juga bisa dalam bentuk cash for work.

\section{Zakat Produktif}

Pendistribusian zakat untuk usaha produktif harus melalui prosedur yang jelas

dan sesuai dengan Keputusan Menteri Agama Republik Indonesia No. 581 Tahun 1999 Tentang Pelaksanaan UU.No 38 Tahun 1999 Tentang Pengelolaan Zakat Pasal 29 yaitu :

1. Melakukan studi kelayakan;

2. Menetapkan jenis usaha produktif;

3. Melakukan bimbingan dan penyuluhan;

4. Melakukan pemantauan, pengendalian dan pengawasan;

5. Mengadakan evaluasi; dan

6. Membuat pelaporan.

$$
\text { Pasal } 29 \text { Keputusan Menteri }
$$

Agama Republik Indonesia no. 581 Tahun 1999 Tentang Pelaksanaan UU.No.38 Tahun 1999 tentang Pengelolaan Zakat tersebut bertujuan untuk memastikan bahwa pelaksanaan usaha produktif dapat berjalan maksimal, serta pelanggaranpelanggaran/penyelewengan tidak akan terjadi atau bisa diminimalisir.Keputusan tersebut memberikan ikatan antara pemberi modal (Amil Zakat) dan penerima modal usaha produktif (faqir miskin) berupa bimbingan, penyuluhan, pemantauan, pengendalian, pengawasan, evaluasi dan pelaporan. sehingga antara penerima pinjaman dan pemberi pinjaman dalam ada ikatan dan berjalan bersamasama untuk mewujudkan tercapainya usaha yang dilakukan oleh faqir miskin.

\section{Hukum Zakat Sebagai Pinjaman Bergulir}


Pendistribusian zakat produktif sebagai modal yang diberikan sebagai pinjaman bagi faqir-miskin, dilihat dari perspektif hukum Islam, membutuhkan kajian yang lebih dalam. Persoalan yang muncul berkaitan dengan tasyaruf berupa pinjaman modal bagi dhuafa' produktif dan bukan berupa uang yang siap dikonsumsi. Dalam hal ini, muncul pertanyaan, benarkah bahwa pinjaman yang diambilkan dari dana zakat merupakan bimbingan ekonomi yang merupakan salah satu metode merealisasikan tujuan zakat yaitu pengentasan kemiskinan, sehingga oleh karenanya, pendistribusian zakat dalam bentuk pinjaman modal bisa dilakukan.

Dalam fiqh Islam, dana zakat didistribusikan sebagai pemberian/hibah, pemindahan hak, sehingga penggunaanya diserahkan sepenuhnya kepada musthahiq sesuai dengan keperluaannya. Namun dmeikian, dalam permasalahan ini terdapat ruang bagi umat Islam untuk melakukan ijtihad, seiring dengan perubahan ruang dan waktu. Hukum Islam mempunyai kemampuan untuk bergerak dan berkembang, mempunyai daya hidup demi sesuai dengan perkembangan dan kemajuan.

Hukum Islam dalam gerakannya mempunyai kaedah asasiyah yaitu ijtihad. Ijtihad yang akan menjawab segala tantangan zaman., dapat memenuhi harapan zaman dengan tetap memelihara kepribadian dan nilai-nilai asasinya (Hasby Ash Shidieqy, 2001).Hukum Islam mudah, jauh dari sulit dan sempit. mudah diamalkan, jauh dari kepicikan segala hukumnya dapat berjalan seiring fitrah manusia, hukum Islam tidaklah sempit melainkan dia luas. Itu berarti penyempurnaan konsep hukum, selalu melibatkan ruang dan waktu yang ada di masyarakat.

Metode pendistribusian zakat yang dilakukan seharusnya bisa memberikan manfaat ubtuk kemandirian umat secara lebih nyat, demi untuk dapat mencapai tujuan zakat. Metode pendistribusian zakat harus bisa mendatangkan kemaslahatan umum karena semakin banyak faqir miskin yang tertolong dapat memenuhi kebutuhan hidupnya dengan usahanya sendiri tanpa terus. Zakat sesungguhnya bukan pemberian sesuap atau dua suap nasi, sehari atau dua hari, kemudian para musthahiq menjadi miskin lagi, akan tetapi kebutuhan hidup secara lebih baik dan dalam waktu yang relatif lama.

Zakat bisa disalurkan sebagai sebuah penyertaan modal produktif dengan sistem bagi hasil. Dasar yang menjadi istimbat hukum pemberian dana Zakat produktif sebagai penyertaan Modal dengan sistem bagi hasil bagi faqir-miskin adalah kaidah maslahah mursalah. 
Kaidah ini menyatakan bahwa pembentukan hukum tidaklahdimaksudkan kecuali untuk mewujudkan kemaslahatan orang banyak. Syaratsyaratmaslahah mursalah dapat dijadikan landasan hukum yaitu :

1. Kemaslahatan yang hakiki dan bukan kemaslahatan yang bersifat dugaansaja. Dari syarat ini dapat dilihat bahwa pendistribusian Zakat produktif bagifaqir-miskin sebagai penyertaan modal denagn sistem bagi hasil, yang pada akhirnya nanti penyertaan yang telah kembali bisa digulirkan kembalikepada faqir-miskin lain akan membawa kemungkinan yang lebih besar bagi faqir-miskin untuk dapat mengembangkan ekonominya sehingga dapatmentas dari kemiskinan yang membelenggu. Diharapkandalam jangka waktu beberapa tahun kedepan dapat mengurangi jumlahfaqir-miskin.

2. Bahwa kemaslahatan tersebut adalah kemaslahatan umum dan bukankemaslahatan pribadi. Artinya kemaslahatan tersebut mendatangkanmanfaat bagi mayoritas umat dan bukan untuk memaslahatan individu /sejumlah perorangan yang merupakan minoritas dari mereka.Dengan pendistribusianzakat sebagai penyertaan modal bergulir dengan sistem bagi hasilmenekankan pada kemaslahatan bagi faqir miskin. . Ini berbeda dengan pemberian cumacuma yang justru akan memungkina kurangnya tanggung jawab mustahik, dan dana zakat yang diberikan kepada faqir-miskin akan habis sebagai bahan konsumsi semata,

3. Bahwa kemaslahatan ini tidak bertentangan dengan hukum atau prinsipyang berdasarkan nash atau ijma'. Kemaslahatan itu sejalan dengankehendak syara'.Mengenai dana zakat sebagai pinjaman, Didin Hafiddudinmembolehkannya dengan alasan pernah terjadi seorang sahabat meminjamseekor ternak kepada Baitul Mal lalu mengembalikannya dengan seekorternak yang lebih baik dari yang ia pinjam (hafidhuddin, 2003). Penyaluran dana zakat sebagai penyertaan yang harus dikembalikan kepada pengelola (amil) berarti bahwa yang diberikan adalah tidak berupa wujud barangnya / uangnya tetapi yangdiberikan adalah manfaat dari barang/uang tersebut. Hal ini dapat diqiaskandengan pendapat Imam Maliki yang membolehkan wakaf dalam jangka waktutertentu, yang hanya diambil manfaat dan hasil dari harta wakaf (Ismail Muhammad Syah, 1992).

Dengam metode 
pendistribusian Zakat produktif sebagai penyertaan bagi faqir-miskin yang kemudian digulirkan kembali diharapkan dapat mewujudkan tujuan zakatsebagai sarana Pengentasan kemiskinan serta mewujudkan kesejahteraan umat.

Pinjaman Bergulir dengan Sistem

\section{bagi Hasil}

Sistem bagi hasil (profit and loss sharing) yang dterapkan untuk pinjaman dana bergulir harus berbasiskan pembagian dari hasil nyata dari keuntungan usaha yang didapatkan atas pemanfaatan dana zakat (based of income). Bagi hasil tidak boleh dilakukan atas proyeksi keuntungan yang berani dijanjikan oleh mustahiq seandainya dana itu digunakan untuk usaha.

Sebuah sifat natural dalam sebuah usaha, yaitu kemungkinan adanya keuntungan atau terjadinya kerugian kerugian harus menjadi dasar utama pengenaan sistem bagi hasil dalam zakat bergulir ini. Jika ada selisih (margin) antara harga jual dengan harga beli, antara total pendapatan dan total biaya dalam suatu usaha, maka para pengusaha mendapatkan keuntungan (profit). Jika selisih itu negatif, maka mereka menderita kerugian (loss).

Pemberian dana zakat bergulir bisa dalam bentuk penyertaan usaha dalam akad mudharabah atau musyarakah.
Nisbah pembagian atas keuntungan harus disepakati di awal. Sedangkan jika terjadi kerugian yang bukan karena kelalaian/kemalasan mustahiq dalam menggunakan dananya, makamustahiq dibebaskan dari kerugian finansial, dengan tidak berkewajiban mengembalikan dana zakatnya. Dalam hal ini, kerugian mustahiq adalah berupa hilangnya kesempatan, waktu, dan tenaga. Untuk hal ini, pendampingan usaha dan pengawasan pemanfaatan dana zakat oleh Organisasi Pengelola Zakat menjadi penting untuk dilakukan.

\section{Profesionalisme Organisasi Pengelola Zakat}

Dalam sistem ini, keberadaan dan kekuatan Organisasi Pengelola Zakat (OPZ) menjadi pilar utama pencapaian tujuan kemanfaatan pendistribusian zakat. Tujuan zakat dalam hal ini akan sulit terwujud tanpa peran aktif dari pengelola zakat. Pengelola zakat harus profesional dalam melakukan pembinaan para mustahiq dalam menjalankan usaha. Pengelola Zakat selayaknya mempunyai tenaga-tenaga ahli dalam bidang manajemen Usaha, dan tenaga-tenaga teknis berkaitan dengan pengelolaan usaha.

Dalam aplikasinya, Zakat Bergulir bisa diterapkan dalam kerjasama pembiayaan di mana pihak OPZ bekerjasama dengan Mustahik dalam 
menjalankan usaha, dengan kontribusi modal dan pembagian keuntungan sesuai kesepakatan yang dibicarakan dan ditentukan dalam kontrak di awal pemberian modal. Pembiayaan Zakat Bergulir bisa dijalankan dalam berbagai bentuk, di antaranya:

Pertama, Zakat Bergulir digunakan untuk pembiayaan modal kerja (working capital), di mana OPZ merupakan partner pada tahap awal dari sebuah usaha atau proses produksi. Dalam model ini, OPZ menyediakan sejumlah uang untuk membeli aset atau alat-alat produksi. Setelah usaha berjalan dan dapat mendatangkan profit, porsi pembiayaan bisa dikurangi (dicicil untuk dikembalikan ke OPZ) hingga akhirnya akan menjadi nol.

Kedua, Zakat Bergulir digunakan untuk pembiayaan jangka pendek. Zakat Bergulir jenis ini bisa diaplikasikan dalam bentuk project finance atau pembiayaan perdagangan, penyediaan bahan mentah atau keperluan-keperluan khusus mustahik untuk menjalankan usahanya.

Terdapat dua metode pembagian keuntungan yang dapat digunakan, yaitu profit sharing (bagi laba) atau revenue sharing (bagi pendapatan). Jika memakai metode revenue sharing, berarti akan dikembalikan ke OPZ adalah bagian keuntungan mustahik tanpa dikurangi dengan biaya-biaya. Sedangkan apabila menggunakan metode profit sharing, maka yang diberikan ke OPZ adalah pendapatan setelah dikurangi biaya-biaya (laba), termasuk di dalamnya setelah Mustahik mengeluarkan zakat atas hasil usahanya tadi.

Model Pembiayaan Zakat Bergulir dengan sistem bagi hasil ini diharapkan bukan menjadi beban bagi mustahik karena adanya kewajiban memberikan sebagian keuntungan sebagai bentuk bagi hasil. Kewajiban mustahik memberikan sebagian keuntungan sebagai bentuk bagi hasil ini sebenarnya lebih diarahkan agar mustahik mempunyai tanggung jawab yang lebih besar dalam memanfaatkan dana zakat yang diterimanya. Bentuk tanggung jawab inilah yang diwujudkan dalam bentuk kewajiban memberikan bagian keuntungan usaha dalam bentuk bagi hasil.

Selain itu, konsep ini daharapkan akan memberikan penekanan kepada mustahik dana untuk secara sunguh-sunguh memperhatikan kesehatan dan profitabilitas usaha yang dijalankannya tersebut. Untuk itu, upaya menyehatkan usaha dengan pengelolaan yang profesional agar usahanya berkembang dan berkelanjutan menjadi tujuan utama para mustahik. Kerjasama dan bantuan dari OPZ sangat dibutuhkan dalam memberikan bimbingan, pendampingan, dan pengawasan atas usaha yang dijalankan Mustahik 
Karena sifat dasarnya, pemberianZakat Bergulir tidak boleh mensyaratkan adanya pemberian jaminan dalam bentuk apa pun oleh mustahik yang diserahkan ke OPZ. Risiko rugi yang dihadapi oleh usaha kerjasama merupakan risiko bersama yang harus dihadapi dan diantisipasi bersama antara Mustahik dan OPZ.

Untuk lebih mengiptimalkan kerja dan fungsinya, OPZ dalam hal ini bisa menjalin kerja sama dengan beberapa lembaga profesional, seperti kementerian koperasi dan UMKM, departemen perindustrian, lembaga-lembaga bisnis, maupun Perguruan Tinggi (PT). Lembaga tadi bisa memberikan bantuan teknis, bantuan manajerial, maupun pembentukan jiwa kewirausahaan agar mustahik, dalam menjalankan usahanya mendapatkan ruang dan kesempatan berkembang yang lebih baik.

\section{Kesimpulan}

Dari uraian di atas, bisa ditarik beberapa kesimpulan:

1. Zakat Bergulir bisa dilaksanakan sebagai alternatif solusi bagi Mustahik yang membutuhkan tambahan dana untuk pengembaknan usahanya atau untuk memulai usaha baru.

2. Pelaksanaan Zakat Bergulir mensyaratkan keterlibatan masing- masing pihak dalam pengelolaan usaha.

3. Organisasi Pengelola Zakat dituntut profesionalisme yang lebih tinggi dalam pengelolaan zakat dan pendampingan, pembimbingan, serta pengawasan usaha yang dijalankan oleh mustahik. .

4. OPZ perlu bekerja sama dengan banyak pihak untuk memberikan kesempatan dan keleluasaan yang lebih bak bagi mustahik yang sedang memulai usaha atau yang sedang mengembangkan usahanya.

5. Dengan ini, maka zakat bukan sekadar pemberian oleh golongan kaya kepada golingan miskin, tetapi sistem zakat diharapkan bisa meningkatkan derajat hidup golongan miskin, dan pada akhirnya menjadi accelerator untukkesetaraan kesejahteraan. InsyaAllah.

\section{DAFTAR PUSTAKA}

Abidin, Hamid., 2004, ReinterprestasiPendayagunaan ZIS, Piramedia, Jakarta

Asy-Sidiqi, Hashbi., 1999, Pedoman

Zakat. PT. Pustaka Rizqi Putra.

Semarang.

Asy-Sidiqi, Hashbi., 2001,Falsafah

Hukum Islam. PT. Pustaka Rizqi

Putra. Semarang 
Hafidhuddin, Didin, 2002, Zakat DalamPerekonomian

Modern, GemaInsani, Jakarta

Hamidi, Luthfi. 2003. Jejak-Jejak Ekonomi Syariah, Senayan Abadi Publishing. Jakarta.

Hasan, Muhammad, 2001, Manajemen Zakat: Model Penglolaan yang Efektif, Idea Press, Yogyakarta

Karim, Adiwarman A. 2001. Ekonomi Islam Suatu Kajian Kontemporer, Gema Insani Press, Jakarta

Khasanah,Umrotul.,2010, Manajemen Zakat Modern: InstrumenPemberdayaanEkonomiU mat, UIN-Maliki Press, Malang Kuntarno Noor, Aflah.,danTajang Mohd. Nasir, 2006, Zakat \&Peran Negara, Forum Zakat, Jakarta.
Muhammad Syah, Ismail, 1992, Filsafat Hukum Islam, Bumi Aksara, Jakarta Qardawi.. Yusuf., 2005, Spektrum Zakat dalam Membangun Ekonomi Kerakyatan (terj.)., Zikrul Hakim, Jakarta.

Sahri, Muhammad, 2006, Mekanisme Zakat \& Permodalan Masyarakat Miskin. Bahtera Press, Malang 